\title{
Authoritarian emigration states: Soft power and cross-border mobility in the Middle East
}

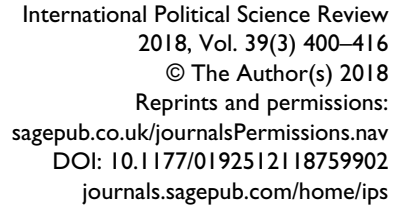

International Political Science Review 2018, Vol. 39(3) 400-416 (C) The Author(s) 2018 Reprints and permissions: sagepub.co.uk/journalsPermissions.nav DOI: I0.1 I77/01925 I2II8759902 journals.sagepub.com/home/ips

๑SAGE

\author{
Gerasimos Tsourapas \\ University of Birmingham, UK
}

\begin{abstract}
Can labor emigration form part of a state's foreign policy goals? The relevant literature links emigration to states' developmental needs, which does not explain why some states choose to economically subsidize their citizens' emigration. This article explores for the first time the soft power importance of high-skilled emigration from authoritarian emigration states. It finds that the Egyptian state under Gamal Abdel Nasser employed labor emigration for two distinct purposes linked to broader soft power interests: first, as an instrument of cultural diplomacy to spread revolutionary ideals of Arab unity and anti-imperialism across the Middle East; second, as a tool for disseminating development aid, particularly in Yemen and sub-Saharan Africa. Drawing on Arabic and non-Arabic primary sources, the article identifies the interplay between foreign policy and cross-border mobility, while also sketching an evolving research agenda on authoritarian emigration states' policy-making.
\end{abstract}

\section{Keywords}

Soft power, diasporas, Egypt, Middle East, authoritarianism, migration, case study, Arab-Israeli conflict

\section{Introduction}

Can labor emigration serve a state's foreign policy goals? In particular, how do authoritarian states use labor emigration in their foreign policy-making? The emerging academic literature on the politics of international migration has yet to fully explore this phenomenon as a separate field of inquiry. In the case of Egypt, the state developed an emigration policy that subsidized the shortterm emigration of high-skilled professionals, who were also loyal supporters of the ruling regime, across the Arab world and Africa. This goes against existing theorization on states' engagement with emigration in two ways: firstly, states are expected to develop labor emigration policies according to their developmental aims, primarily seeking to accrue migrant remittances; however,

\section{Corresponding author:}

Gerasimos Tsourapas, Department of Political Science and International Studies, University of Birmingham, Birmingham, BI5 2TT, UK.

Email: g.tsourapas@bham.ac.uk 
the Egyptian case demonstrates how authoritarian states may also be willing to financially support the emigration of high-skilled citizens. Secondly, comparative politics research links emigration in authoritarian contexts to the 'exit' of political dissenters; yet, the case of Egypt highlights how thousands of regime followers were also willing to emigrate abroad in support of the state's foreign policy goals. A closer analysis of 'authoritarian emigration states' is needed in order to fully comprehend the politics of cross-border mobility in non-democratic contexts. This includes the export of Cuban medical staff under the Fidel Castro regime or the dispatch of Russian scientific staff across the Soviet Union. Beyond Cold War politics, China's 'no-strings-attached' development policy currently involves the dispatch of hundreds of thousands of workers, advisors, and technicians employed in aid and construction projects abroad, particularly in Africa.

This article aims to shed light on the motivation of authoritarian emigration states for promoting their citizens' cross-border mobility, in an attempt to move beyond political economy and comparative politics paradigms that dominate the field. I argue that they may employ high-skilled labor emigration as an instrument of soft power for two distinct foreign policy purposes, namely cultural diplomacy and bilateral aid dissemination. In the case of Egypt under President Gamal Abdel Nasser (1954-1970), the sending state employed regional emigration of Egyptian professionals as a tool of cultural diplomacy in order to disseminate ideas of anti-colonialism, anti-Zionism, and Egyptian-led pan-Arabism across the Arab world; it also employed emigration as an instrument of bilateral aid dissemination, particularly in sub-Saharan Africa and in the case of Yemen. In these practices of winning the 'hearts and minds' of Arab and African states' citizens, Egypt came into direct competition with the conservative Arab monarchies that felt threatened by Nasser's popularity and pan-Arab rhetoric, as well as Israel, which was also organizing the dispatch of professionals abroad as an instrument of bilateral aid. Beyond its contribution to the interplay of cross-border mobility and authoritarian states' foreign policy, the article also contributes to a more nuanced understanding of the importance of migration in conflictual intra-Arab relations and the ArabIsraeli conflict, as well as the interaction of soft and hard power in the broader context of the international relations of the Middle East.

I employ a single-case methodology for two reasons: first, it may provide a challenge to existing theoretical paradigms, paving the way for future large- $N$ studies. In this instance, I argue for the foreign policy importance of high-skilled emigration within the context of authoritarian states. In particular, I demonstrate how an authoritarian emigration state may engage in high-skilled labor emigration not for regime export but for soft power purposes of cultural diplomacy and bilateral aid dissemination. Despite the pitfalls of selecting cases on the dependent variable, a significant body of political science work highlights how 'in the early stages of a research program, selection on the dependent variable can serve the heuristic purpose of identifying the potential causal paths and variables leading to the dependent variable of interest' (George and Bennett, 2005: 23). This is the case with Egypt, which constitutes a 'crucial,' albeit not a 'hard' case in terms of its relevance to the article's theoretical construct (Gerring, 2007), given its historical centrality as the main exporter of migrant labor in the Middle East and one of the largest recipients of remittances globally (Tsourapas, 2015), as well as its character as an authoritarian state.

Second, the single-case format allows for the presentation of rich data on Egypt, particularly primary accounts that may be cited in full and inductively allow for theory development (George and Bennett, 2005: 111-112). Two hypotheses emerge based on existing data on the Egyptian historical case: Egyptian professionals' emigration under Nasser served as a political instrument during the intra-Arab competition against conservative monarchies (James, 2006; Kerr, 1978; Tsourapas, 2016); at the same time, high-skilled emigration formed part of its broader foreign assistance to the developing world, particularly Yemen (Rahmy, 1981; Schmidt, 1968). Detailed evidence from primary sources will allow for a reformulation of these initial explanations into 
more general hypotheses, which may then be tested in a broader set of cases. As George and Bennett argue, 'it is valid to develop a theory from a case and then test the theory against additional evidence from the case that was not used to derive the theory,' as this enhances the theory's falsifiability and 'can circumvent confirmation biases' (2005: 112).

With regard to data collection, fieldwork in authoritarian contexts presents unique challenges, particularly in light of the fact that cross-border mobility is traditionally considered a security issue for Arab elites (Tsourapas, 2014). Research is further plagued by a lack of publicly available statistical data on intra-Arab flows, as well as by the fact that Egyptian migration management is handled at the highest levels of the executive. At the same time, the fact that this is a historical case study hinders the use of elite interviews. In the absence of readily available information on state policy or statistical data, I relied upon a meticulous collection of the coverage of Egyptian labor migration issues: I collected all references to issues of emigration in three main Egyptian newspapers (al-Ahram, al-Akhbar, al-Gumhuriya) and a number of other Egyptian sources, which featured fragments of policy analysis or statistical information. I also succeeded in gaining access to archival sources at the Ministry of Education in Cairo, which allowed for a more accurate understanding of the politics of Egyptian educational staff emigration. I sought to neutralize any bias in Egyptian data sources via triangulation with additional Western evidence, namely autobiographies and memoirs, material from the National Archives in London, and various Western media coverage of labor migration in the 1954-1970 period. Given the broader anti-Nasser climate across many Western states during this period, I assigned more weight to evidence drawn from first-hand accounts in instances of discrepancies or contradictions.

\section{Authoritarian emigration states in international relations}

Labor emigration has been mainly examined through political economy and comparative politics analyses, neither of which has linked cross-border mobility to sending states' foreign policy. For political economists, labor emigration policy is shaped by a state's developmental needs, particularly with regard to attracting remittances (Kapur, 2010). Although this strand of literature identifies how cross-border mobility features in uneven relations between 'developed (migration receiving) and less-developed (migration sending) countries' (Hollifield, 2012: 366), it does not incorporate foreign policy matters in its analysis. At the same time, comparative political scientists examining emigration out of authoritarian contexts expect such flows to be dominated by regime dissenters seeking to 'exit' the sending state, rather than regime loyalists that may serve foreign policy purposes abroad (cf. Glasius, 2017).

That is not to say that the foreign policy component of cross-border migration has been unexamined. Within the subfield of diaspora studies, Gamlen introduced the concept of the 'emigration state' to describe state institutions, practices, and mechanisms 'protruding beyond their borders and impacting on a variety of extra-territorial groups' (Gamlen, 2008: 840; cf. Hollifield, 2004). At the same time, a growing number of scholars theorize the foreign policy importance of diasporas along two lines: one group of scholars employ diasporas as their unit of analysis, and theorize their foreign policy repercussions for the sending state (King and Melvin, 2006; Koinova, 2012); a second group of scholars focus on the sending state, and how it is able to employ diaspora groups as lobbying instruments (Mearsheimer and Walt, 2008; cf. Shain and Barth, 2003). Yet, states' rationale for their diaspora and labor emigration policies do not overlap (cf. Tsourapas, 2015): for instance, Israel's diaspora policy towards Jewish Americans that form part of the Israel lobby in the USA does not imply the existence of a particular labor emigration policy. At the same time, there has been little attention paid to whether regime type matters in such policies (Koinova and Tsourapas, 2018; for an exception, see Mirilovic, 2016). 
Table I. Egyptian teachers in Arab and other countries, 1953-1964.

\begin{tabular}{lc}
\hline Year & Teachers in Arab states \\
\hline $1953-1954$ & 580 \\
$1955-1956$ & 1198 \\
$1958-1959$ & 2696 \\
$1961-1962$ & 2948 \\
$1962-1963$ & 3512 \\
$1963-1964$ & 4615 \\
\hline
\end{tabular}

Source: 'Comparative statistics of teachers delegated by the Ministry of Education' (1965).

This article presents a new perspective for the analysis of mobility across non-democratic contexts in international relations scholarship, aiming to shift debates beyond state-diaspora thinking and to put regime type to the forefront of analysis. I argue for the need to examine the workings of 'authoritarian emigration states,' namely the set of institutions, practices, and mechanisms regulating cross-border mobility developed within non-democratic contexts. How do foreign policy considerations feature in authoritarian emigration states' strategies or, put differently, in their emigration diplomacy (Tsourapas, 2017)? A number of empirical examples suggests how authoritarian emigration states may employ high-skilled emigration in their foreign policy agendas, including the export of Cuban medical professionals across Latin America, Africa, and the Middle East (Kirk and Erisman, 2009), or the dispatch of Russian scientists and bureaucrats across the Eastern bloc (Babiracki, 2015). How can this foreign policy aspect of authoritarian emigration states' actions best be examined?

In order to address this, I introduce the concept of 'soft power' to the study of migration and diaspora politics, with an empirical focus on the international politics of the Middle East. While a full analysis of the term is beyond the scope of this analysis (cf. Berenksoetter and Williams, 2007), this article's conceptualization is reminiscent of Lukes' third dimension of power or, as Joseph Nye puts it, 'getting others to want the outcomes you want' via co-option rather than coercion (Nye, 2004: 5). While soft power has yet to be associated with cross-border mobility, I argue that it allows a more accurate analysis of the foreign policy importance of high-skilled emigration for authoritarian states as an instrument of cultural diplomacy via academic and scientific exchanges (Nye, 2004: 44-55), and facilitating the dissemination of developmental aid (Nye, 2004: 61-62). In the remainder of the article, I examine how soft power considerations shaped Egyptian labor emigration policy under President Gamal Abdel Nasser. Beyond the interplay between Egyptian foreign and emigration policies, I also identify how soft power is not entirely benign nor detached from hard power in the international politics of the Middle East, as per Nye's original theorization, but is closely associated with both military and economic power (cf. Schmidt, 2007).

\section{Emigration and Egyptian soft power under Gamal Abdel Nasser, 1954-1970}

How does labor migration feature in Egypt's foreign policy in the 1954-1970 period? Egyptian emigration before 1970 was tightly regulated (Dessouki, 1982; Tsourapas, 2015), with the notable exception of the encouragement of regional, short-term emigration of Egyptian professionals. Under the state's secondment program (nizām al-i 'āra li-l-khārij), thousands of teachers (Table 1), doctors, nurses, and other professionals were dispatched according to the Nasserite regime's wish to contribute to the development processes of neighboring Arab states. The state also aimed at spreading 
revolutionary ideas of anti-imperialism and Arab unity, or pan-Arabism, under Nasser's leadership, by applying the regime's dictum that 'we should differentiate between Egypt as a state, and Egypt as a revolution' (cf. James, 2006; Kerr, 1978). The Egyptian regime developed a number of propaganda instruments to spread revolutionary ideas across the Arab world - the most well-known being the Voice of the Arabs radio programs. That said, very little has yet been written about how short-term, high-skilled emigration complemented its foreign policy goals (cf. Tsourapas, 2016).

Egypt's regional foreign policy underwent a number of stages in the aftermath of the 1952 Free Officers' Revolution (Gordon, 1992). An initial phase of introspection and pre-occupation with expelling the British gradually gave way to a more cautious, albeit at times openly hostile, attitude towards the West. By the mid-1950s, Nasser was firmly in control of Egypt and empowered by the fortuitous results of the Suez Crisis two years later. He developed an Egypt-centered, panArab rhetoric that combined 'anti-colonialism, Arab socialism and the ideal of Arab political union' and reverberated across the Middle East (Dekmejian, 1971: 108-118; James, 2006). References to al-wahda al- 'arabiyya (Arab Unity) would increase after Egypt's 1958 merger with Syria and the creation of the United Arab Republic (Jankowski, 2002: 27-39). This rhetoric was widely popular across the Middle East, but Arab masses' enthusiasm for the ideas of Nasserism was not shared by elites in the conservative Arab monarchies. In particular, King Faisal, who in 1964 had replaced his brother Saud on the throne of Saudi Arabia, saw 'Nasser's pan-Arabism as a direct threat to the survival of the Sa'udi ruling group' (Al-Rasheed, 2010: 113). This tension between the Arab republics and the Arab monarchies, the so-called Arab Cold War (Kerr, 1978), culminated in Egyptian and Saudi support for opposing sides in the 1962-1970 Yemeni Civil War, which will be described below.

In this process of intra-Arab antagonism, the Egyptian regime was able to employ regional migration as an instrument of soft power, partly given the massive developmental needs that the Arab world faced at the time. In the twilight of British colonial rule over the region, there was a heightened need for trained professionals to staff new Arab states' educational and bureaucratic machineries. In fact, in the era of decolonization, 'mass popular education was one of the first tasks which the new governments set themselves' (Hourani, 2013: 389). Under Nasser, the Egyptian state was able to take advantage of this historical conjuncture. In fact, while labor emigration under Nasser was heavily restricted and regulated through a variety of formal and informal bureaucratic obstacles, regional high-skilled emigration constituted the notable exception to this (Tsourapas, 2016). This form of migration, particularly of Egyptian educators, was framed in political terms: as al-Gumhuriya reported, 'Egypt believes that it is her duty to help her sister Arab states to develop their education and learning ... and that this development will not be achieved unless Egypt supplies these states with their needs for teachers at any cost' ('Egypt and the Arabs', 1957).

Very little evidence exists on the nature of the process of selection and training, and even archival material on this is fragmentary (see Table 2). Yet one is able to gain a better understanding through published sources, governmental documents, and various first-hand accounts: Charles Cremeans, for instance, a British teacher working in the Arab world at the time, wrote that Egyptians were 'indoctrinated before going to their foreign posts and are instructed to act as representatives of their country and its policies' (Cremeans, 1963: 41). Egyptian ministries prepared 'training seminars' for teachers, aiming to 'acquaint them with the countries that they will be serving at' and 'to enlighten them' (United Arab Republic, 1964: 5). Dessouki has also written on how those aiming to be seconded abroad needed to have no criminal record, and to expressly state that they would 'not work with an agency openly hostile to Egypt or its national interest [or] undermine the development goals of Egypt' (1982: 62).

But why was this a soft power strategy for the Egyptian regime, rather than merely another instance of economically driven labor emigration? For one, this was a very costly process for the 
Table 2. Egyptian teachers seconded to Arab states by destination (1953-1962).

\begin{tabular}{lcrrrrrrrr}
\hline Country & 1953 & 1954 & 1955 & 1956 & 1957 & 1958 & 1959 & 1960 & 1961 \\
\hline Saudi Arabia & 206 & 293 & 401 & 500 & 454 & 551 & 727 & 866 & 1027 \\
Jordan & - & 8 & 20 & 31 & 56 & - & - & - & - \\
Lebanon & 25 & 25 & 39 & 36 & 75 & 111 & 251 & 131 & 104 \\
Kuwait & 114 & 180 & 262 & 326 & 395 & 435 & 490 & 480 & 411 \\
Bahrain & 15 & 15 & 18 & 25 & 25 & 25 & 26 & 28 & 36 \\
Morocco & - & - & - & 20 & 75 & 81 & 175 & 210 & 334 \\
Sudan & - & - & - & - & 580 & 632 & 673 & 658 & 653 \\
Qatar & - & 1 & 3 & 5 & 8 & 14 & 17 & 18 & 24 \\
Libya & 55 & 114 & 180 & 219 & 217 & 232 & 228 & 391 & 231 \\
Yemen & - & 12 & 11 & 8 & 17 & 17 & 17 & 14 & 0 \\
Iraq & 76 & 112 & 121 & 136 & 63 & 449 & - & - & - \\
Palestine & 13 & 32 & 34 & 37 & 46 & 120 & 166 & 175 & 165 \\
Somalia & - & - & 25 & 23 & 57 & 69 & 90 & 109 & 213 \\
\hline
\end{tabular}

Source: 'Comparative statistics of teachers delegated by the Ministry of Education' (1965).

Egyptian state: with regard to Egyptian teachers, the Ministry of Education was typically responsible for their salaries while they were abroad (Tsourapas, 2016). At the same time, as Table 2 demonstrates, host states appeared to be selected on the basis of close relations with Egypt: for instance, the deterioration of relations between Egypt and Jordan or Iraq led to the cancellation of secondment provisions for those countries. More importantly, the short-term emigration of Egyptian professionals, particularly teachers, was allowed despite severe domestic shortages: according to an eye-witness account, 'the export of teachers was a sacrifice to Egyptians ... up and down the Nile valley, it is common sight to see Egyptian schoolrooms empty for lack of teachers' (Wynn, 1959: 136). Numerous reports also point to the heavy politicization of these Egyptians abroad, who would 'take with them the flame of Nasser-type nationalism' (Ibid. 137). It is not accidental that the Egyptian state published lists of teachers selected for service abroad in the main newspapers, as an act of valorization (see 'Teachers selected for secondment,' 1956). The following section examines in detail how this form of migration was aimed at promoting Egyptian cultural diplomacy goals across the region.

\section{High-skilled emigration and Egyptian cultural diplomacy}

Broadly, a strategy of cultural diplomacy developed after 1954, which aimed at disseminating ideas of an Egyptian-led Arab unity, anti-colonialism, and anti-Zionism across the Middle East (Barnett, 1998; James, 2006). This had a number of components: for one, Egypt sponsored radio programs, notably al-Sawt al-'Arab (Voice of the Arabs), which were broadcast across the Middle East and enjoyed enormous popularity. The distribution of Egyptian newspapers abroad was also employed in the context of the Arab Cold War as an instrument of Egyptian propaganda (Kerr, 1978). Education was also a very important foreign policy tool, particularly in allowing Arabs to pursue degrees in Egypt, frequently under Egyptian state scholarships. In fact, Nasser himself made the connection between regional political influence and education by calling the Voice of the Arabs 'an open university' that provided 'education in national consciousness' (quoted in Abou-El-Fadl, 2015: 232). But how was high-skilled regional emigration linked to cultural diplomacy? 
In Libya, Egyptian professionals promoted Nasserite ideals, particularly Arab unity and anticolonialism, in a number of ways. In 1954, Britain's ambassador to Libya, Sir Alec Kirkbride, reported to the then Foreign Secretary, Sir Anthony Eden, how:

Egypt is the nearest source of supply for Arab officials, many parts of the Libyan administration are modelled on the Egyptian pattern and lastly the Egyptian Government continues to pay the salaries of Egyptian civil servants seconded to Libya and allows them to draw, in addition, the Libyan salaries attached to their posts ('Political relations between Libya and Egypt: Growing influence of Egypt', 1954).

But it was Egyptian teachers that the British were worried about. Kirkbride warned that:

the most damage to British interests is being done by the considerable number of Egyptian teachers who are employed in the Libyan schools. These people are in a position to poison the mind of the rising generation of Libyans against the Western Powers in general and against Great Britain in particular (ibid.).

One example of this phenomenon is the Libyan secondary school curriculum, as developed and taught by Egyptian teachers:

The presence of Egyptian teachers explains why so many classrooms show the influence of Egyptian propaganda. Pupils do crayon drawings of Egyptian troops winning victories over Israel or Britain. In Benghazi, Libya, a complete course in Egyptian history is given to secondary school students. A display in a high school art exhibit showed pictures of the leading rulers of Egypt; on one side were the 'bad' rulers, on the other the 'good' rulers. The bad rulers began with the Pharaoh Cheops, who enslaved his people to build the pyramids, and ended with Farouk. The good rulers began with the idealistic Pharaoh Ikhnaton and ended with, of course, Gamal Abdel Nasser (Wynn, 1959: 137).

Nasserite cultural diplomacy across the country was aided by the fact that Libyan schools were using Egyptian textbooks. The seventh-grade textbooks featured a dedicated chapter entitled 'I am an Arab' that stated: 'I am an Arab. Yes, I say it with all pride and happiness. I am not alone. Every Arab is my brother in language, religion, feeling and nationhood... Yes, I am an Arab from Libya' (Obeidi, 1999: 37). But, importantly, Egyptian cultural diplomacy in Libya involved the dispatch of other professionals - the Libyan labor code was drafted by Egyptian legal scholars, while the country's first university, the Libyan University, was initially run by Egyptian academics ('InterArab relations', 1961: 150). More broadly, the New York Times' coverage of the country described how Libya had

large contingents of Egyptian teachers, advisers, and government administrators [whose] penetration into almost every field of Libyan life has become a matter of Western alarm. For these Egyptians are also helping carry on Premier Nasser's anti-Western campaign. There are almost 500 Egyptian teachers in Libyan secondary schools (Caruthers, 1956).

Beyond North Africa, Egyptians 'played a major role in the development of the political and cultural consciousness of [Arab] nationalism in Bahraini society' (Chalcraft, 2010: 8). Similarly, Egyptian teachers in Dubai were involved in attempts to spread Nasserite ideas and foster students' political activism, as 'many young boys were encouraged by senior students and expatriate staff to demonstrate in the streets while carrying banners and photos of Jamal Abdel Nasser' (Davidson, 2008: 41). The diary of Donald Hawley, a British diplomat and writer stationed in Dubai at the time, describes in detail a variety of forms of Egyptian-led political activism, including the decoration of school classrooms with pictures of Nasser and the recitation of Nasser's speeches. In Iraq, the government claimed that 
teachers were a potent factor in the spread of Nasser propaganda and that they helped incite youths to demonstrations that resulted in eleven deaths [in November 1956], mostly in Mosul. [Teachers were found to] have agitated against the regime by encouraging students to howl on streets for severance of relations with Britain and France ('Iraq Dismissing Cairo Teachers', 1957).

Beyond educational staff, Egyptian professionals were recruited in 'the Codification Department of the Ministry of Justice, in the Oil Affairs Department of the Ministry of Economics, and in the Government Oil Refineries Administration ...' ('Further correspondence respecting Iraq: Part 12', 1958).

British archival sources paint a similar picture in Kuwait, where the Director of Education had been Egyptian himself, until 1950 ('Further correspondence respecting Arabia', 1957). In the aftermath of the 1956 Suez Crisis, Egyptian teachers were reported to have organized a countrywide boycott of foreign goods, enforced by 'young women patrols (mostly Egyptian teachers) who started going round in twos and threes visiting shops and preaching to the shopkeepers the sin of selling to the foreigner'. The report highlighted how 'it would appear that all [women patrols] are Egyptians' ('Security situation in Persian Gulf states', 1956). While it is imperative that the alarmist nature of these reports be put into the broader historical context of decolonization and Great Britain's concerns over the power of Nasser across the Arab world, multiple sources acknowledge how the Kuwaiti 'education system and the social clubs [appear to be] completely Egyptian influenced' (Brewer, 1957). A British account of a sports gala organized in May 1957 in Minaa' Shuweekh indicates the extent of the interplay between the export of Egyptian teachers and cultural diplomacy in Kuwait: it describes how 2100 Kuwaiti secondary school students participated in the event:

The tune which welcomed spectators just before the gala began was that of the favourite song of 'Voice of the Arabs.' It was entitled, 'Woe to the Colonisers' ... The historical tableaux which appeared in the program included: a representation of the battle of Port Said [in the context of the Suez Crisis], which took the form of a float bearing a boat with sailors and an effigy of a descending parachutist. The sailors in the boat were shooting down the parachutist. Written in large letters on the side of the float was: 'Get out of my Canal' ... A physical training display which was the last event in the programme, consisted of exercises performed to the tune of a song specially composed for the occasion by an Egyptian inspector of education. Each verse of this song recalled one of the Arab states: Egypt was represented as the champion of Arab freedom and the repeller of the aggressors; Yemen as the protector of Aden who was called upon to liberate her; Syria was described as the home of true nationalism, while Iraqis were the subject of sarcastic praise for their skill in picking dates with their finger-tips ... These points together with the lengthy displays in which hundreds of small boys took part with air-rifles, made this gala nearer in character to a military rally than to a sporting event ('Internal political situation in Kuwait,' 1957).

How effective was the export of high-skilled Egyptians across the Arab world in constituting an effective strategy of cultural diplomacy under Nasser? The difficulty of accurately measuring both soft power and its effects is well-established. That said, one indication of its effectiveness - besides the archival and media sources previously cited - lies in local elites' responses. In Libya, King Idris reportedly attempted to identify Egyptian teachers engaging in the dissemination of pan-Arabism by using secret police agents disguised as students: 'the planting of secret police in class-rooms in secondary schools may seem grotesque, but it is to be remembered that many of the twenty-one and twenty-two year old pupils are very grown up in appearance' a British 1965 report argues, concluding that 80 Egyptian teachers were duly deported, with Libya bringing in Tunisians instead ('Action against Egyptian teachers', 1965). Iraqi elites employed similar strategies to counter Nasserism when 25 teachers were expelled in 1957, although this was 'carried out with restraint' and without 
targeting higher education professionals 'who are still needed' (The New York Times, 17 May 1957). Beyond elites' attempts at combatting the phenomenon, a wide variety of anecdotal data points to the soft power effects of Egyptian high-skilled migration on the 'hearts and minds' of the Arab world - Hawley's memoirs include a notable event in which a group of young boys shouted at him on a Dubai street, in 1961: 'Down with colonization and long live Gamal!' (Hawley, 2007: 116).

\section{High-skilled emigration and Egyptian development aid}

The use of high-skilled migration as an instrument of soft power did not rest solely on cultural diplomacy. Across a number of host states, Egyptian migration diplomacy facilitated the dispersal of development aid, either in the form of expertise or in terms of infrastructural support. This is most evident in Egyptian emigration in sub-Saharan Africa, particularly across newly independent African states. As regime stalwart Muhammad Hasanayn Haykal declared in 1956, 'Egypt must send selected missions of experts in science, religion, politics, economics, commerce and social services to aid the African peoples, to support them, to collaborate with them and light the path before them' (Haykal, 1956: 22). Egyptian development aid across Africa had a distinct foreign policy component: firstly, Egypt believed it stood to gain potential support at the United Nations from the newly independent African nations (Cremeans, 1963); secondly, and perhaps more importantly, it aimed to battle the involvement of Israel in the continent. In 1965, Nasser wrote the following:

The struggle of the Asian and African peoples is not waged in isolation from the struggle of the Arab nation. In addition to the responsibilities of the development of the African continent following its liberation call for gigantic efforts so that imperialism should not infiltrate and return to it under the pressure of underdevelopment or behind a deceptive mask, such as the Israeli mask, which imperialism tries actively to make use of in Africa (Nasser, 1966: 12).

In terms of Israel, it was also engaged in a sustained effort to increase its visibility across Africa via the work of the Agency for International Development Cooperation in the Ministry of Foreign Affairs (MASHAV). Founded in 1958, MASHAV organized development projects across Africa, usually centered around three stages: (a) a survey on the potential development of a certain field (cooperative, institutional, agricultural, scientific, and so on) led, and usually funded, by Israel; (b) African citizens coming to Israel for a short period to study at educational institutions affiliated with MASHAV; and (c) a team of Israeli experts going to a given African state to complete or initiate a project, usually funded by the African state or through a joint venture with an Israeli company (Kreinin, 1964: 18). This initiative was rhetorically associated with the ancient Jewish concept of tikkun olam, or 'repairing the world' - providing a mythological source for an altruistic discourse of Third World empowerment, which discounted more immediate Israeli goals: firstly, ensuring African states' support for Israel at the United Nations (where the African bloc was gaining significant voting power, given the General Assembly's one-state, one-vote policy); and, secondly, strengthening ties with Western states, particularly the USA, by precluding African states from obtaining development support from the Soviet Union.

Egyptian policy in sub-Saharan Africa came into competition with Israel. This is not to say that Cairo did not attempt to include cultural diplomacy aspects (for an example of how it engaged in anti-colonial rhetoric, see Figure 1). Mostly, however, Egypt was concerned with Israel's development policy. According to the New York Times, Nasser was particularly keen to preclude Israeli influence across these states; as a result, 'the Egyptians [made] themselves heard everywhere in Africa and play[ed] the part of self-chosen leaders' (Love, 1956). As Haykal describes: 
Figure I. African liberation ('Cairo carries the torch of liberty for the black continent', 1960).

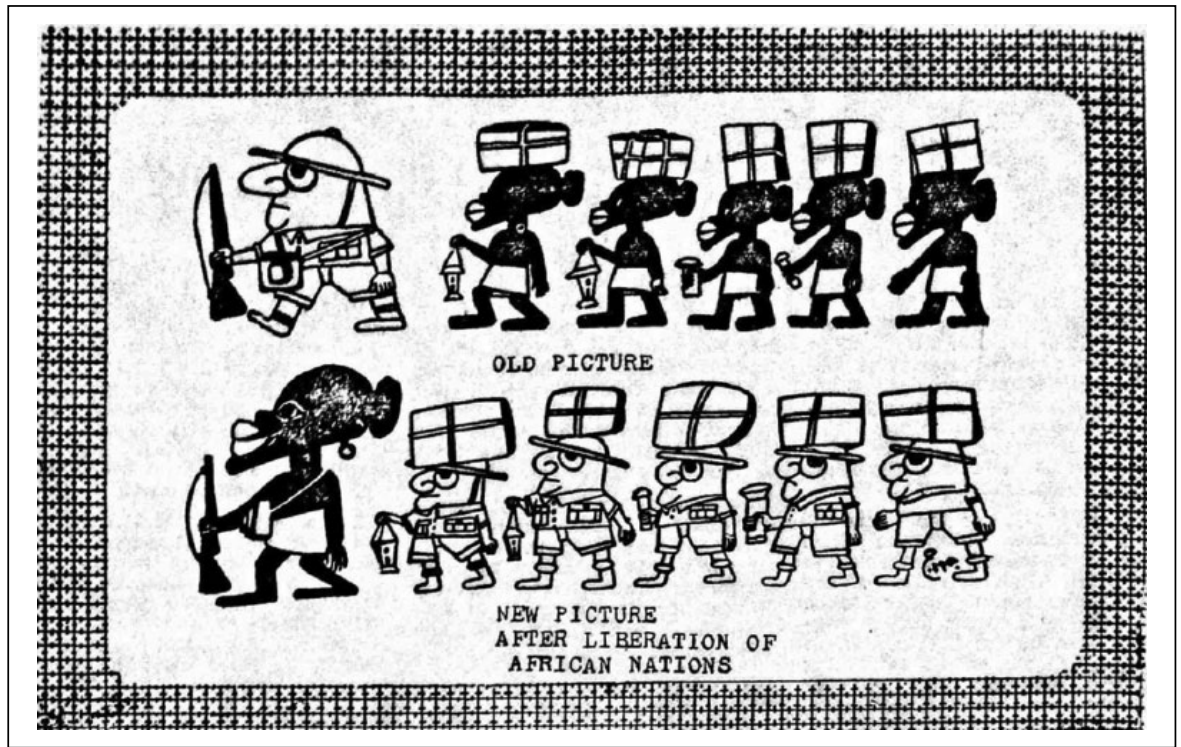

The day a newly independent African country celebrates its independence, a delegation arrives from Israel bringing with it a deep and detailed study of the problems of the country. While all other delegations are offering their congratulations the Israeli delegation is speaking about the problems [that] the newly independent country faces. Most delegations return home after the celebrations but the African ruler keeps the Israeli envoy because he can discuss post-independence problems with him. ... In many cases, an Israeli mission returns bearing with it economic, technical and/or cultural agreements. Israel usually chooses one or two fields and concentrates its activities on these. For example, construction is considered the easiest and profits are positive. Any building [that] rises in any African country continues to be a symbol of Israel's activities. After comes trade and maritime companies, then agricultural centres. Also, Israel chooses her men in Africa very carefully. And its embassies in Africa are comprised of the most efficient men from the foreign ministry (Haykal, 1964).

Beyond Africa, Egyptian use of emigration as a form of development aid is most evident in the case of Yemen between 1962 and 1970. Despite Egyptians' political activism, the Yemeni leader, Imam Ahmad bin Yahya, found it very difficult to send them away for he relied on them for the country's development. Aiming for the institution of a revolutionary movement in Yemen that would align with Egypt, Nasser came into a protracted, direct conflict with conservative Arab leaders - particularly Saudi Arabia's King Faisal - who saw in this an attempt to destabilize the region and threaten their survival. The conflict in Yemen escalated into a proxy war between Egypt - or, as it was then called, the United Arab Republic - and Saudi Arabia (Dawisha, 1975). Beyond a heavy military engagement of over 60,000 soldiers, Egypt also organized the short-term emigration of thousands of professionals - teachers, engineers, doctors, nurses, and so on (Figure 2) - to the country.

Already in March 1958, Egyptian teachers had organized a crowd of 500 protesters, who marched to the Palace and demonstrated against the Imam. The extent to which these Egyptians constituted a form of soft power in the proxy war against Saudi Arabia became evident in Sana'a. As British sources recount: 'all Egyptian teachers [marched] together with 2,000 demonstrators' towards the Saudi Arabia Delegation in Sana'a, where they 'broke into the courtyard and smashed all the windows'. The Imam was forced to issue a formal apology to the Saudi King, saying 'we 
Figure 2. Egyptian nurses in Yemen ('Yemen, the revolution that tipped the balance', 1964).

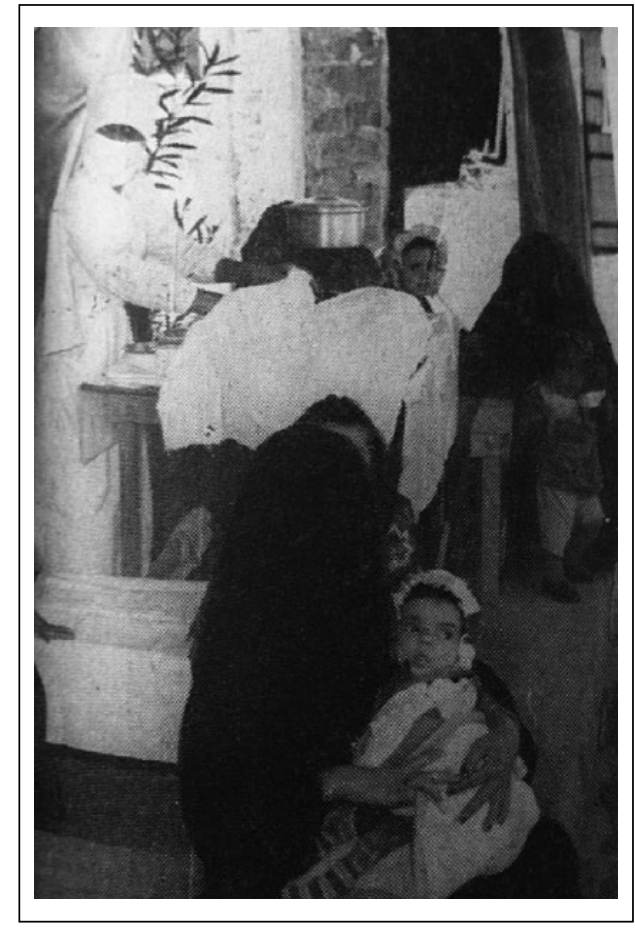

are Arab brothers and must accept sorrow with good heart' ('Internal political situation in Yemen', 1959). Yemen's heavy dependence on Egyptian professionals for its development highlights the foreign policy importance of Egyptian regional emigration at the time. Only a few months following the protest, the Imam 'welcomed' new Egyptian professionals in Hodeida, saying that Yemen was waiting for Egyptian 'experts to start building the first Yemeni spinning and textile factory' ('Summary of World Broadcasts; the Middle East and Africa', 1959). O' Balance explains:

Partly because there was no alternative, Egyptians working in the country as military instructors, school teachers and doctors, all subtly and insidiously aided the spread of Nasser's views ... All this had a profound effect on young, restless, impressionable minds in the Yemen [resulting in August 1962] demonstrations in some of the secular schools against alleged approval by the Imam of the American bases in Saudi Arabia (O’Ballance, 1971: 63).

In late 1959, a number of different pamphlets, originating from Egypt, were intercepted by the British in Ta'izz (Figure 3). They read:

Oh sons of Yemen, the army and the people! ... Do not clap for Gamal. O sons of Yemen whose hearts are shaken whenever Gamal is mentioned and whose tongues constantly speak of him. Gamal Abdel Nasser does not need your applause nor does he require your admiration ... Your biggest compliment to Gamal would be when you united together and organise yourselves, eliminating the monarchy and declaring the birth of the new Yemeni People's Republic ('Internal political situation in Yemen', 1959).

Egypt intensified its soft power strategy in Yemen following the Imam's death in September 1962. Abdullah al-Sallal, the main challenger to the Saudi-backed Yemeni monarchy, declared the creation 
Figure 3. Egyptian pamphlets intercepted in Yemen ('Internal political situation in Yemen', 1959).

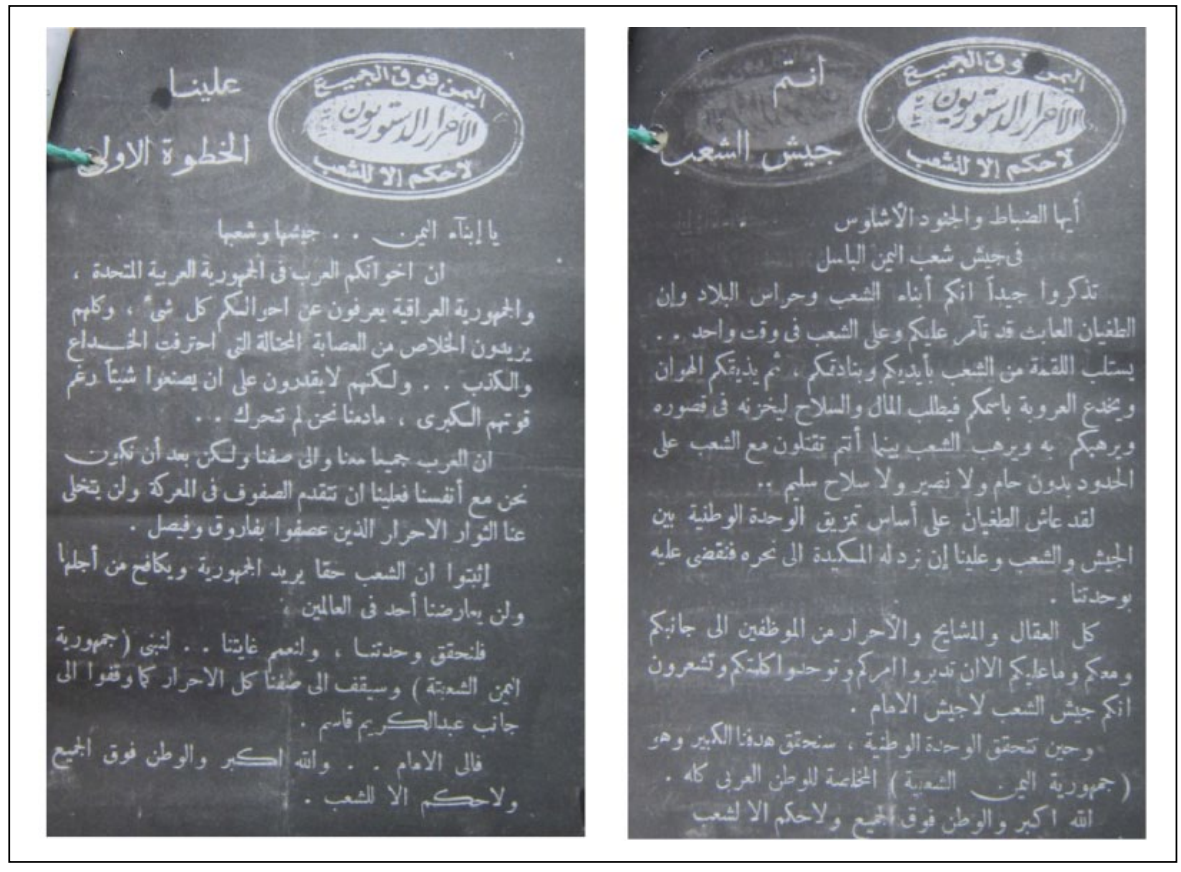

of the Yemen Arab Republic and, immediately, 'appealed to Egypt primarily for support against potential foreign intervention, from Saudi Arabia or the British in Aden, and for Egyptian technical and administrative help' (Tsourapas, 2016: 339). Following al-Sallal's appeal, 'Egypt moved into Yemen, not only with tanks, jets and soldiers, but also with almost 300 primary and secondary school teachers, administrative advisors, doctors for the new hospitals'. In terms of development aid as soft power, as the Egyptian Director of the Technical Aid Office for Yemen argued:

[Cairo] took great care to send to Yemen the best teams and experts in spite of their being badly needed in [Egypt ...] Experts from the ... Ministry of Scientific Research and the Ministry of Agriculture were sent to Yemen ... Economists and finance experts were also seconded to Yemen and the result was the emergence of a State Budget covering the expenses and revenues for a whole year; the first of its kind in the history of Yemen (quoted in Arab Observer, 5 October 1964).

Egypt's involvement in Yemen highlights not merely the importance of labor emigration as a soft power strategy, but also the degree to which soft power interacted with economic and military power. Dana Adams Schmidt, the New York Times' correspondent, produced a detailed account of the military conflict in Yemen, while also paying particular attention to Egyptian soft power policy:

I was impressed also by the extent of the Egyptians' 'hearts and minds' campaign among the Yemenis [such as] installing water pumps, school-teaching and providing all kinds of professional services and advice - agricultural, engineering and medical. These were all ways of introducing the Yemenis to modern life, ways in which the Egyptians could do things for the Yemeni people which their traditional leaders could not. The Egyptians had also brought 100 Egyptian ulema [Islamic scholars] into the country, in the hopes of persuading the Yemenis that there were really no important differences between the Sunnis and the Shia in general, and the Shaffei and Zeidi sects in particular. They may even have tried to persuade the Zeidis that they did not really need an Imam (Schmidt, 1968: 208). 


\section{Conclusion}

The novel evidence presented in this article via the case study of Egypt under Nasser allows the reformulation of initial hypotheses into two broader ones: first, the Egyptian authoritarian state was able to employ labor emigration in support of its cultural diplomacy strategies abroad. In fact, the targeted, state-sponsored emigration of Egyptian teachers contributed to the spread of ideas of panArabism, anti-Zionism, and anti-colonialism across the Arab world. Second, high-skilled professionals' emigration facilitated the dissemination of bilateral aid, particularly across African states and in Yemen. This goes against existing theorization of international migration politics both with regard to political economy accounts that expect emigration policies to be driven by states' development or macroeconomic interests, as well as comparative politics accounts that focus on political dissenters' emigration out of authoritarian contexts. It also shifts the debate within diaspora studies beyond the foreign policy component of state-diaspora relations, by examining the distinct process of labor emigration. Overall, the Egyptian case exhibits a distinct soft power component in the strategies developed by a major authoritarian emigration state, a component that cannot be as easily disassociated from economic or military power as Nye would think. Rather, the workings of the Egyptian authoritarian emigration state imply an interaction of soft and hard power.

The article's two hypotheses on the foreign policy strategies of an authoritarian emigration state may be tested in a broader set of cases. In terms of using emigration as an instrument of cultural diplomacy, the Soviet Union during the Cold War dispatched hundreds of high-skilled Russian scientists and bureaucrats across the Eastern bloc as a way of contributing to host states' development and instilling communist ideals. The rationale behind Moscow's policy is arguably best understood through a foreign policy rather than a developmental or comparative politics lens. Similarly, Castro's rise to power in Cuba spearheaded the policy of 'medical internationalism,' through which Cuba would financially support the emigration of thousands of medical staff - doctors, nurses, and so on - across Latin America and Africa for cultural diplomacy purposes. Egyptian and Israeli use of emigration as a foreign aid component within the context of the Arab-Israeli rivalry is reminiscent of the Cold-War-era competition between the two superpowers over the Third World. Similarly, there exist a number of similarities between intra-Arab rivalry and the competition between China and the USSR over the leadership of the communist world during the Cold War. In all these cases, cross-border mobility has been an important aspect of authoritarian emigration states' foreign policy agendas.

Ultimately, the article aims to contribute to an evolving research agenda on the politics of authoritarian emigration states. Through its inductive exploration of population mobility as part of an authoritarian state's soft power strategies, it aims to bring work on soft power into conversation with research on the international politics of migration, and to shift focus away from the policies of liberal democracies. In this sense, the article aims to draw parallels with ongoing research on the international politics of authoritarian rule, on authoritarian regime export strategies, as well as work on linkage and leverage. In doing so, it is able to shed additional light on key matters in world politics: the rise of China as a global power cannot be disassociated from 'wenhua ruan shili,' or the cultural soft power it pursues in a number of ways, including the dispatch of Chinese teachers to over 500 Confucius Institutes across the world. In the Middle East, the Iranian-Saudi competition also includes a transnational dimension of efforts at exerting religious influence beyond the two states' borders. Similarly, Turkish foreign policy includes a soft power dimension in its emigration diplomacy, as the Diyanet, the Directorate of Religious Affairs, trains, funds, and dispatches thousands of imams annually to over 2000 mosques abroad.

Future work is needed beyond single-case studies in order to test, and modify, the expectations set out in this article, and to create a more robust model of the interplay between authoritarian emigration and foreign policy. At the same time, empirical studies may be able to address 
additional questions raised by this article. For one, how does high-skilled emigration fit into the broader range of soft power policies available to authoritarian states? For Nasserite Egypt, highskilled emigration was only one component of the state's broader soft power agenda; today, China and Turkey combine emigration with a number of other soft power policies, while Cuban strategy appears to focus on the dispatch of medical staff abroad. How effective is high-skilled emigration as an instrument of authoritarian soft power? Egypt avoided dispatching professionals to more powerful or antagonistic states - a policy mirrored by Cuba's export of medical staff to 'friendly' states across the Global South. Yet, Turkish emigration diplomacy is more extensive, sponsoring the short-term emigration of imams across Europe and North America. Finally, are there different ways through which authoritarian emigration states may employ cross-border mobility in their foreign policy agendas beyond high-skilled emigration? Many authoritarian emigration states Egypt, China, Turkey, Saudi Arabia - have also developed extensive education programs offering scholarships and assistance to public officials and students from targeted countries. Iranian hawzas, seminaries for the training of Shi'a Muslim clerics in Qum and Najaf, include over 10,000 nonIranian students. The mechanisms and dynamics of authoritarian emigration states' soft power strategies constitutes an important, underexplored field of inquiry in the study of world politics.

\section{Acknowledgements}

The author wishes to thank the IPSR editorial team, the anonymous reviewers, Ibrahim Awad, Maysa Ayoub, Irene Fernandez-Molina, Adam Quinn, and Stefan Wolff for their help and feedback. Maria Koinova offered insightful comments on multiple drafts. Noam Chen-Zion provided expert research assistance. An earlier version of this paper was presented at the American University in Cairo, as well as in workshops held at SOAS, University of London, the University of Amsterdam, and the University of Birmingham.

\section{Funding}

This research has been supported by the Council for British Research in the Levant, Pilot Study Award on 'Migration Diplomacy in the Eastern Mediterranean - Inter-State Politics of Population Mobility in the Middle East' (2017-2018 Pilot Study Award), and by a British Academy/Leverhulme Small Research Grant [Grant Number SG163246]. The author also gratefully acknowledges funding provided by the School of Government and Society, University of Birmingham.

\section{ORCID ID}

Gerasimos Tsourapas (D) https://orcid.org/0000-0002-2746-9752

\section{References}

Abou-El-Fadl, Reem (2015) Neutralism Made Positive: Egyptian Anti-Colonialism on the Road to Bandung. British Journal of Middle Eastern Studies 42(2): 219-240.

Action against Egyptian teachers (1965). FO 371/184264. London: The National Archives.

Ahmadov, Anar K and Gwendolyn Sasse (2016) A Voice Despite Exit: The Role of Assimilation, Emigrant eNetworks, and Destination in Emigrants' Transnational Political Engagement. Comparative Political Studies 49(1): 78-114.

Al-Rasheed, Madawi (2010) A History of Saudi Arabia. 2nd edn. New York: Cambridge University Press. Babiracki, Patryk (2015) Soviet Soft Power in Poland Culture and the Making of Stalin's New Empire, 19431957. Chapel Hill: The University of North Carolina Press.

Barnett, Michael N (1998) Dialogues in Arab Politics: Negotiations in Regional Order. New York: Columbia University Press.

Berenksoetter, Felix and Michael J Williams (2007) Power in World Politics. London: Routledge.

Brewer, Sam Pope (1957) Cairo Propaganda Stirs Kuwait, But State's British Tie is Strong. The New York Times, 15 March: 4. 
Cairo carries the torch of liberty for the black continent (1960). Arab Observer. Cairo: National Publications House, 10 July: 17-21.

Caruthers, Osgood (1956) Egyptians Wooing of Libya Stirs Concerns of Western Diplomats. The New York Times, 24 May: 1-5.

Chalcraft, John (2010) Monarchy, Migration and Hegemony in the Arabian Peninsula. London: LSE Kuwait Programme on Development, Governance and Globalisation in the Gulf States.

Collyer, Michael (ed) (2013) Emigration Nations: Policies and Ideologies of Emigrant Engagement. New York: Palgrave Macmillan.

Comparative statistics of teachers delegated by the Ministry of Education (1964). Cairo: Department of Secondment, Ministry of Education.

Cremeans, Charles Davis (1963) The Arabs and the World: Nasser's Arab Nationalist Policy. New York: Praeger.

Davidson, Christopher M (2008) Dubai: The Vulnerability of Success. New York: Columbia University Press.

Dawisha, A I (1975) Intervention in the Yemen: An Analysis of Egyptian Perceptions and Policies. Middle East Journal 29(1): 47-63.

Dekmejian, R Hrair (1971) Egypt Under Nasir: A Study in Political Dynamics. Albany, NY: State University of New York Press.

Dessouki, Ali E Hillal (1982) The Shift in Egypt's Migration Policy: 1952-1978. Middle Eastern Studies 18(1): 53-68.

Egypt and the Arabs (1957) al-Gumhuriya, 8 June.

Further correspondence respecting Arabia: Part 12 (1957). FO 464/12. London: The National Archives.

Further correspondence respecting Iraq: Part 12 (1958). FO 481/12. London: The National Archives.

Gamlen, Alan (2008) The Emigration State and the Modern Geopolitical Imagination. Political Geography 27(8): 840-856.

George, Alexander L and Andrew Bennett (2005) Case Studies and Theory Development in the Social Sciences. Cambridge, MA: MIT Press.

Gerring, John (2007) Is There a (Viable) Crucial-Case Method? Comparative Political Studies 40(3): 231253.

Glasius, Marlies (2017) Extraterritorial Authoritarian Practices: A Framework. Globalisations. Available at: https://doi.org/10.1080/14747731.2017.1403781.Published Online :7 December.

Gordon, Joel (1992) Nasser's Blessed Movement Egypt's Free Officers and the July Revolution. New York: Oxford University Press.

Hawley, Donald (2007) The Emirates: Witness to a Metamorphosis. Wilby, Norwich: Michael Russell.

Haykal, Muhammad Hassanein (1956). An African policy for Egypt. The Egyptian Economic \& Political Review, Monthly Review of Politics and Economics in the Middle East. Cairo: The Egyptian Political \& Economic Review, August: 21-24.

Haykal, Muhammad Hassanein (1964). To combat Israel Heikal calls for plan in Africa. Arab Observer. Cairo: National Publications House, 10 August: 8-9.

Hollifield, James F (2004) The Emerging Migration State. International Migration Review 38(3): 885-912.

Hollifield, James F (2012) Migration and International Relations. In Marc R Rosenblum and Daniel J Tichenor (eds) The Oxford Handbook of The Politics of International Migration. Oxford: Oxford University Press, 345-382.

Hourani, Albert Habib (2013) A History of the Arab Peoples. London: Faber \& Faber.

Inter-Arab relations (1961) Middle East Record, Volume Two. Tel Aviv: Tel Aviv University - The Reuven Shiloah Research Center.

Internal political situation in Kuwait (1957) FO 371/126899. London: The National Archives.

Internal political situation in Yemen (1959) CO 1015/1267. London: The National Archives.

Iraq Dismissing Cairo Teachers (1957) The New York Times, 17 May: 6.

James, Laura M (2006) Nasser at War: Arab Images of the Enemy. Basingstoke: Palgrave Macmillan.

Jankowski, James P (2002) Nasser's Egypt, Arab Nationalism, and the United Arab Republic. Boulder, CO: Lynne Rienner Publishers.

Kapur, Devesh (2010) Diaspora, Development, and Democracy: The Domestic Impact of International Migration from India. Princeton, NJ: Princeton University Press. 
Kerr, Malcolm H (1978) The Arab Cold War: Gamal 'abd Al-Nasir and His Rivals, 1958-1970. 3rd ed. London: Oxford University Press.

King, Charles and Neil J Melvin (2006) Diaspora Politics: Ethnic linkages, foreign policy, and security in Eurasia. International Security 24(3): 108-138.

Kirk, John M and H Michael Erisman (2009) Cuban Medical Internationalism - Origins, Evolution, and Goals. New York: Palgrave Macmillan.

Koinova, Maria (2012) Autonomy and Positionality in Diaspora Politics. International Political Sociology 6(1): 99-103.

Koinova, Maria and Gerasimos Tsourapas (2018) How Do Countries of Origin Engage Migrants and Diasporas? Multiple Actors and Comparative Perspectives. International Political Science Review (in this special issue).

Kreinin, Mordechai E (1964) Israel and Africa: A Study in Technical Cooperation. New York: Praeger.

Love, Kennett (1956) Zanzibar A Target. The New York Times, 1 March: 2.

Malyarenko, Tatyana and Stefan Wolff (2018) The logic of competitive influence-seeking: Russia, Ukraine, and the conflict in Donbas. Post-Soviet Affairs. Available at: https://doi.org/10.1080/10605 86X.2018.1425083.Published online :15 February.

Mearsheimer, John J and Stephen M Walt (2008) The Israel Lobby and US Foreign Policy. London: Penguin.

Mirilovic, Nikola (2016) Regime Type and Diaspora Politics: A dyadic approach. Foreign Policy Analysis. Available at: https://doi.org/10.1093/fpa/orw038.Published online :28 April.

Nasser, G A (1966) On Africa. Cairo: Ministry of National Guidance, Information Administration.

Nye, Joseph S (2004) Soft Power: The Means to Success in World Politics. New York: Public Affairs.

O'Ballance, Edgar (1971) The War in the Yemen. London: Faber.

Obeidi, Amal (1999) Political Culture in Libya. Richmond: Curzon.

Political relations between Libya and Egypt: Growing influence of Egypt (1954) File 10316: FO 371/108687. London: The National Archives.

Rahmy, Ali Abdel Rahman (1981) The Egyptian Policy in the Arab World: Intervention in Yemen, 19621967: Case Study. Geneva: University of Geneva.

Schmidt, Brian C (2007) Realism and Facets of Power in International Relations. In Felix Berenskoetter and Michael J Williams (eds) Power in World Politics. London: Routledge: 43-63.

Schmidt, Dana Adams (1968) Yemen: The Unknown War. London: Bodley Head.

Security situation in Persian Gulf States (1956) FO 371/120558. London: The National Archives.

Shain, Yossi and Aharon Barth (2003) Diasporas and International Relations Theory. International Organization 57(3): 449-479.

Summary of World Broadcasts; the Middle East and Africa (1959) British Broadcasting Corporation, 19 January.

Teachers selected for secondment (1956) al-Ahram, 11 July.

Tsourapas, Gerasimos (2014) Notes from the Field: Researching emigration in post-2011 Egypt. American Political Science Association Migration \& Citizenship Newsletter 2(2): 58-63.

Tsourapas, Gerasimos (2015) Why Do States Develop Multi-Tier Emigrant Policies? Evidence from Egypt. Journal of Ethnic \& Migration Studies 41(13): 2192-2214.

Tsourapas, Gerasimos (2016) Nasser's Educators and Agitators across al-Watan al- 'Arabi: Tracing the foreign policy importance of Egyptian regional migration, 1952-1967. British Journal of Middle Eastern Studies 43(3): 324-341.

Tsourapas, Gerasimos (2017) Migration Diplomacy in the Global South: Cooperation, Coercion, and Issue Linkage in Gaddafi's Libya. Third World Quarterly 38(10): 2367-2385.

United Arab Republic (1964) Al-Ta' 'ìm Al-'ālì : Mushkilātuh Wa-Usus Takhtītih. Cairo: Wizārat al-Ta'līm al-'Ālì.

Wynn, Wilton (1959) Nasser of Egypt: The Search for Dignity. Clinton, MA: Colonial Press.

Yemen, the revolution that tipped the balance (1964) Arab Observer and the Scribe. Cairo: National Publications House, 5 October: 20-23. 


\section{Author biography}

Gerasimos Tsourapas is a Lecturer in Middle East Politics at the Department of Political Science and International Studies, University of Birmingham, UK, where he works on the politics of migration and refugee movements in the Middle East. He is currently the Principal Investigator in two research projects: 'The Politics of Forced Migration in the Mediterranean: Interstate Bargaining and Issue-Linkage in Greece and Jordan', funded by a British Academy/Leverhulme grant, and 'Migration Diplomacy in the Eastern Mediterranean - Inter-State Politics of Population Mobility in the Middle East', funded by the Council for British Research in the Levant. 